\title{
Thyroid gland as an initial site of delayed metastasis from renal cell carcinoma: A case report
}

\author{
Mutahir A. Tunio, Mushabbab A IAsiri, Yasser Bayoumi, Mohsin Fareed, Shoaib Ahmad \\ Department of Radiation Oncology, Comprehensive Cancer Center, King Fahad Medical City, Riyadh, PO 59046, Saudi \\ Arabia
}

Correspondence: Mutahir A. Tunio. Address: Department of Radiation Oncology, Comprehensive Cancer Center, King Fahad Medical City, Riyadh, PO 59046, Saudi Arabia. Telephone: 96-612-889-999. E-mail: drmutahirtonio@hotmail.com

Received: February 16, 2012

Accepted: March 1, $2012 \quad$ Published: August 1, 2012

DOI : $10.5430 /$ jst.v2n4p50

URL: http://dx.doi.org/10.5430/jst.v2n4p50

\section{Abstract}

Renal cell carcinoma (RCC) has unpredictable and diverse behavior. The classic triad of hematuria, loin pain and abdominal mass is uncommon. About, 25\%-30\% of patients are found to have metastases at the time of diagnosis. Bones, lungs, liver and brain are the frequent sites of metastases. RCC with metastasis to the thyroid gland is rarest manifestation. We report a case of 40 years old male who underwent radical nephectomy for localized RCC seven years back, now presented with swelling in neck which was suspected as thyroid malignancy; subsequently was confirmed as metastatic RCC following excisional biopsy and was treated with surgical resection.

\section{Key words}

Renal cell carcinoma, Metastasis, Thyroid gland

\section{I ntroduction}

Renal cell carcinoma (RCC) has unpredictable and diverse behavior. The incidence of RCC over last 20 years has progressively increased due to widespread use of modern imaging ${ }^{[1]}$. About $30 \%-50 \%$ of patients are found to have metastases at diagnosis. While bone, lymph nodes, lungs and brain constitute expected 'homing' sites, metastasis may turn up at the unusual locations (skin, testis and maxillary antrum) ${ }^{[2,3]}$.

Metastasis of RCC to thyroid gland is also rare manifestation. Most common tumors which metastasize to thyroid are the breast, lung and kidney and in some cases they are detected only at autopsy ${ }^{[4]}$. To differentiate a primary thyroid malignancy from RCC, although the clinical and radiographic findings are often nonspecific, the histopathological and Immunohistochemical features are sufficiently distinctive.

Herein, a rare case of thyroid gland metastasis, following an open radical nephrectomy six years back in a 40 years old male with a stage pT2NOM0 and Fuhrman grade II renal cell carcinoma, is reported. 


\section{Case report}

A 40 years old man patient presented during routine follow-up with 4 month history of painless swelling in neck. Past history revealed that six years back, he underwent left radical nephro-ureterectomy right Gibson's incision; the histopathological findings were was consistent with papillary cell type renal cell carcinoma. Tumor was not infiltrating through the capsule. Hilar vessels, margins and bladder cuff were free of tumor. Stage was made pT2N0M0.

On physical examination, there was hard fixed palpable superficial mass in thyroid gland. The rest of examination was normal. Ultrasonography (USG) revealed a hypoechoic mass in left lobe of thyroid. Thyroid function tests (T4, TSH and thyroglobulin levels) were within normal limits. USG-guided fine needle aspiration (FNA) cytology of the left thyroid nodule was nondiagnostic on two separate occasions. A computed tomography (CT) scan of his neck was performed which revealed a mass of $2 \mathrm{~cm} \times 2 \mathrm{~cm}$ size in left lobe of thyroid gland with vascular enhancement and $1 \mathrm{~cm}$ nodule on right lobe. No cervical lymphadenopathy was found and post-nephrectomy renal bed was clear (Figure.1). The bone scan and CT chest revealed no metastases. Subsequently left lobectomy of thyroid gland was performed. Histopathological analysis of left lobe of thyroid gland confirmed metastatic clear cell RCC (Figure 2). Completion thyroidectomy was refused by patient and no further adjuvant therapy was given to the patient. At 6-month postoperative followup, the patient showed no signs of thyroid recurrence but developed bone, lung and skin metastases. He was started on sunitinib $50 \mathrm{mg}$ daily. At 9 months patient was on follow up with partial response to sunitinib.

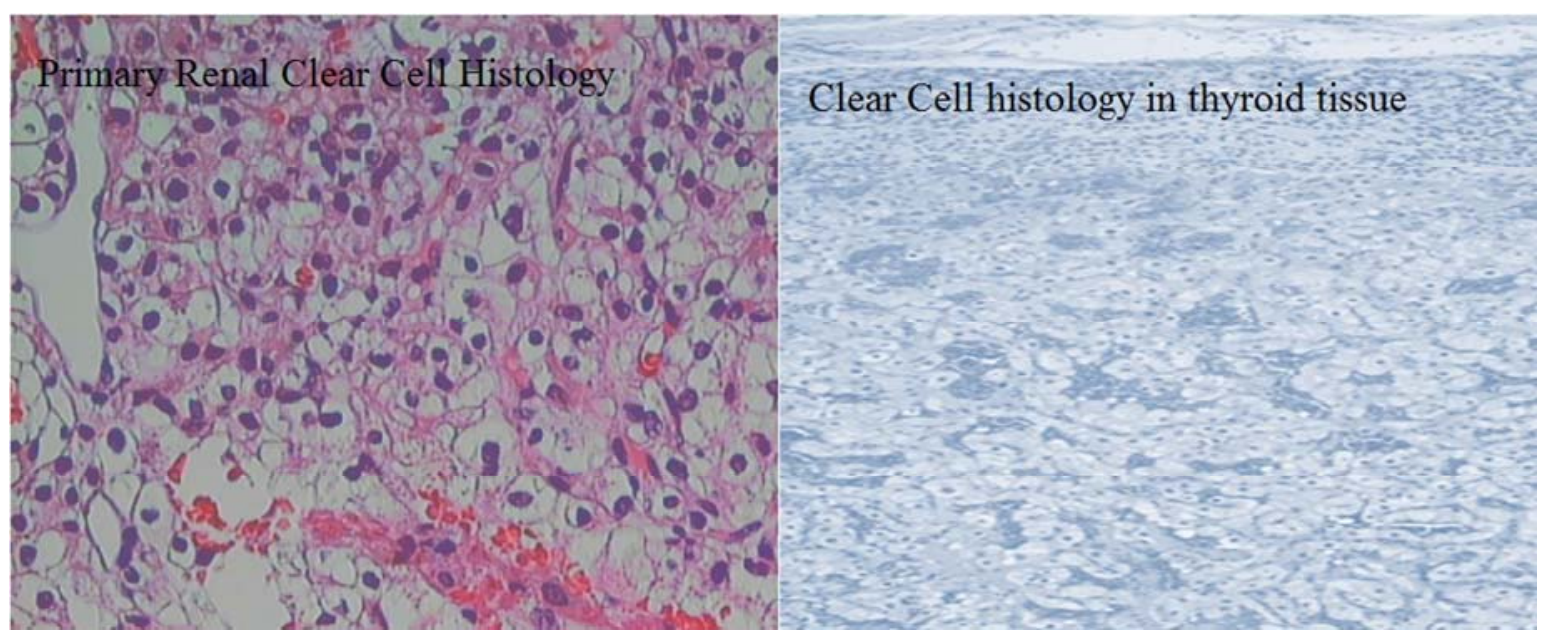

Figure 1. CT scan of neck showing thyroid gland mass

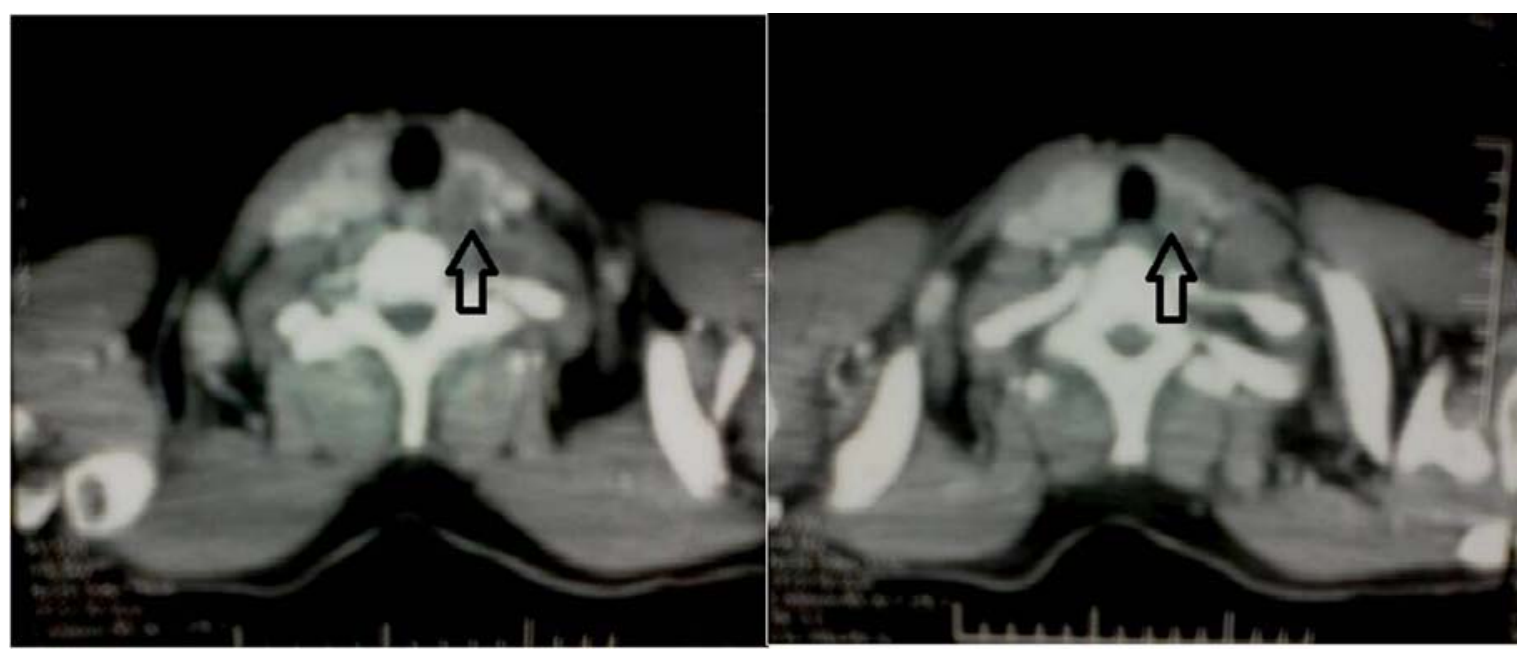

Figure 2. Microphotograph showing clear cell histology of renal cell carcinoma 


\section{Discussion}

Metastasis to the thyroid gland is an uncommon manifestation. However, autopsy results show that $1.9 \%$ to $22.4 \%$ of patients with generalized malignancies have metastasis to the thyroid gland ${ }^{[5]}$. According to one large autopsy series, malignant melanoma (39\%) and breast carcinoma (21\%) account for the largest number of tumors metastasizing to the thyroid gland as part of widely disseminated disease (excluding lymphoma and leukemia) and thyroid gland metastases from renal cell carcinoma are rarest ${ }^{[6]}$.

Clinical presentation as a mass in the thyroid gland that proves to be metastatic is very uncommon. However, when a thyroid mass presents as the clinical manifestation of metastatic disease, RCC seems to be the most frequent tumor type ${ }^{[7]}$. Although micro-metastases are present in about $25 \%$ of RCCs at the time of the diagnosis of the primary malignancy (synchronous), metastatic disease can develop as part of the latency of the tumor with delayed development of metastases after many years of dormancy (metachronous) as seen in our patient ${ }^{[8]}$.

The thyroid gland is one of the most vascularized organs in the body and one would expect it to be the site of metastatic disease. It has been suggested that the thyroid gland, when altered by goiter, neoplasms, or thyroiditis, is more vulnerable to metastatic growth due to metabolic changes with a decrease in oxygen and iodine content ${ }^{[9]}$.

Surgical treatment of patients with solitary thyroid gland metastases is recommended because of the unusually good prognosis in patients reported in the literature when they were treated with definitive surgical therapy with mean 5-year survival rate $30-60 \%{ }^{[10]}$.

In conclusion, thyroid metastases secondary to RCC are rare and surgical treatment is recommended.

\section{Conflict of interests}

The authors declare that there is no conflict of interest statement.

\section{References}

[1] Tunio MA, Hashmi A, Rafi M. Need for a new trial to evaluate postoperative radiotherapy in renal cell carcinoma: a meta-analysis of randomized controlled trials. Ann Oncol. 2010; 21: 1839-45. PMid: 20139152 http://dx.doi.org/10.1093/annonc/mdq028

[2] Tunio MA, Hashmi A, Rafi M. Epistaxis and proptosis- Unusual primary manifestations of metastatic renal cell carcinoma. Pak J Med Sci. 2009; 25: 1012-14.

[3] Tunio MA, Hashmi A, Rafi M. Renal cell carcinoma presenting as skin and ipsilateral testicular metastasis. Isra Medical Journal. 2009; 1: 79-81.

[4] R. Cotellese, P. Noccioli, T. Francione, D. Angelucci, R. Zappacosta, and L. Napolitano, et al. Thyroid metastasis from renal carcinoma. Clinical case. Chirurgia Italiana. 2002; 54: 861-67. PMid: 12613336

[5] Heffess CS, Wenig BM, Thompson LD. Metastatic renal cell carcinoma to thyroid gland. A clinicopathologic study of 36 cases. Cancer. 2002; 95: 1869-78. PMid: 12404280 http://dx.doi.org/10.1002/cncr.10901

[6] Lasser A, Rothman JG, Calamia VJ. Renal-cell carcinoma metastatic to the thyroid. Aspiration cytology and histologic findings. Acta Cytol. 1985; 29: 856-58. PMid: 3863434

[7] Chen H, Nicol TL, Udelsman R. Clinically significant, isolated metastatic disease to the thyroid gland. World J Surg. 1999; 23: 177-80. PMid: 9880428 http://dx.doi.org/10.1007/PL00013162

[8] Kihara M, Yokomise H, Yamauchi A. Metastasis of renal cell carcinoma to the thyroid gland 19 years after nephrectomy: A case report. Auris Nasus Larynx. 2004; 31: 95-100. PMid: 15041062 http://dx.doi.org/10.1016/j.anl.2003.09.002

[9] Koo HL, Jang J, Hong SJ, Shong Y, Gong G. Renal cell carcinoma metastatic to follicular adenoma of the thyroid gland. A case report. Acta Cytol. 2004; 48: 64-68. PMid: 14969183 http://dx.doi.org/10.1159/000326285

[10] Machens A, Dralle H. Outcome after thyroid surgery for metastasis from renal cell cancer. Surgery. 2010; 147: 65-71. PMid: 19878964 http://dx.doi.org/10.1016/j.surg.2009.08.015 